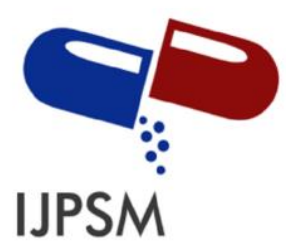

Choudhary Kapil et al, Int. Journal of Pharmaceutical Sciences and Medicine (IJPSM),

Vol.6 Issue. 8, August- 2021, pg. 134-143

ISSN: 2519-9889

Impact Factor: 3.426

\title{
Synthesis and Characterization of Benzimidazole Derivatives for Antimicrobial Property
}

\author{
Choudhary Kapil*; Bhavsar Rupali; Chaturvedi Prerna \\ Dept. of Pharmaceutical Chemistry, Swami Vivekanand College of Pharmacy, Indore (M.P) India \\ DOI: 10.47760/ijpsm.2021.v06i08.009
}

\begin{abstract}
Benzimidazoles are an important class of compounds with a wide spectrum of biological activity ranging from anti-hypertensive, anti-viral, anti-microbial, antitumor and anthelmintic activity. Benzimidazole rings are the most important nitrogen-containing heterocycles, which are widely explored and utilized by the pharmaceutical industry for drug discovery. Due to their special structural features and electron-rich environment, Benzimidazole containing drugs bind to a variety of therapeutic targets, thereby exhibiting a broad spectrum of bioactivities. Numerous benzimidazole based drugs have been extensively used in the clinic to treat various types of diseases with high therapeutic potential.

The main objective of present work was to study the anti-microbial activity of the Benzimidazole derivatives. A series of benzimidzole derivatives have been synthesized and identified. The compounds were synthesized by using ethyl acetate and benzene as starting material. The series of 1,2-disubstituted benzimidazoles containing pyrimidine and other functional groups was prepared which provides advantages such as, easy workup and high yield. All reagents used for synthesis were of synthetic grade. Purification of all compounds was done by thin layer chromatography using silica gel $\mathrm{G}$ as absorbent on glass plate using acetate: benzene $(6: 4 \mathrm{v} / \mathrm{v} \%)$, Toluene: Acetone $(8: 2 \mathrm{v} / \mathrm{v} \%)$ and Ethyl Acetate: $\mathrm{n}$ - Hexane $(6: 4 \mathrm{v} / \mathrm{v} \%)$ as mobile phase. Compounds were detected by using iodine vapor as detecting agent. All compounds show single spot. All the newly synthesized compounds were characterized by IR spectral study. The compounds were investigated for their antimicrobial activity against clinical standard drug Ciprofloxacin. The anti-microbial study of the synthesized derivative was done Broad panels of bacterial and fungal strains were used for testing the antimicrobial properties of the synthesized molecules III1-13. The compounds IIII $\left(\mathrm{m}-\mathrm{NO}_{2}\right), \mathbf{I I I}_{2}\left(\mathrm{p}-\mathrm{NO}_{2}\right), \mathbf{I I I}_{3}(\mathrm{~m}-\mathrm{Cl}), \mathbf{I I I}_{\mathbf{4}}(3-\mathrm{F}-4-\mathrm{Cl})$ and $\mathbf{I I I} \mathbf{9}\left(\mathrm{p}-\mathrm{OCH}_{3}\right)$ showed excellent activity $(62.5 \mu \mathrm{g} / \mathrm{ml})$, even better than ciprofloxacin.
\end{abstract}

Keywords: Benzimidazole, Derivatives, Anti-microbial Activity, Ciprofloxacin, Spectral data.

\section{INTRODUCTION}

Benz imidazole is an amphoteric compound as they possess both acidic and basic characteristics. The NH group present in Benz imidazole is relatively strongly acidic and weakly basic. Benz imidazole makes an important constituent of naturally occurring Vit$\mathrm{B} 12^{\mathbf{5 6}}$ and is a structural unit of nucleotide, due to which it easily interacts with the biopolymers of living system and this interaction is responsible for its numerous biological aspects, since proteases have been linked with several disease states Benz imidazole exhibits numerous biological aspects like antihelminthic, antifungal, anti-allergic, antimicrobial, 


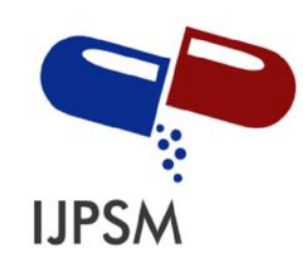

Choudhary Kapil et al, Int. Journal of Pharmaceutical Sciences and Medicine (IJPSM),

Vol.6 Issue. 8, August- 2021, pg. 134-143

ISSN: 2519-9889

Impact Factor: 3.426

antiviral, antineoplastic, antioxidant, anticancer, antihypertensive, anti-inflammatory, analgesic, antiprotozoal, anti-hepatitis B virus, antiulcer and anticonvulsant ${ }^{1}$ activities. Benzimidazoles with their two ring systems bearing different functional substituents leads to essential modification of the physico-chemical metabolic and pharmacokinetic properties of these drugs. In the past few decades, the incorporation of Benz imidazole nucleus have received much attention due to their Anti-microbial values.

Microbial disease are responsible for a significant of death worldwide and according to the world health organization cancer is increasing world's largest problem. Unfortunately, however a number of the current clinically efficacious anticancer agents are becoming less active because of development of anticancer resistance. A long standing scientific research has shown that Benz-imidazole shows important biological properties such as anti-cancer, anti-malarial, anti-microbial, antibacterial and anti-oxidant activities. There is an urgent need for the discovery or optimization of novel anti-microbial agents.

The present work is aimed to find heterocyclic linked Benz imidazole as antimicrobial agents.

\section{MATERIALS AND METHOD MATERIALS}

The marketed formulation of ciprofloxacin tablet manufactured by Cipla was procured from local market. All the chemicals used were analytical grade and were purchased from Merck Specialties Private Limited, Mumbai, India.

\section{INSTRUMENTATION:}

FTIR spectrophotometer was used to carry out spectral analysis and the data was recorded by Hitachi software. Standard and sample drugs were weighed by using Denver electronic chemical balance (SI234) and Melting point was determined by using Melting point apparatus BTI. ApparatusReflux condenser by WENSAR is also used.

\section{EXPERIMENTALS}

\section{EXPERIMENTAL PROCEDURE FOR THE SYNTHESIS OF BENZIMIDAZOLE DERIVATIVES:}

\section{A. Synthesis of 5-methoxy-1-H-benzo[d]imidazole-2-thiol I (step 1)}

Ethanol $(40 \mathrm{ml})$ and potassium hydroxide $\left(0.01 \mathrm{~mol}, 56.11 \mathrm{gm} / \mathrm{mol}, 0.56 \mathrm{gm}\right.$ in $\left.2 \mathrm{ml} \mathrm{H}_{2} \mathrm{O}\right)$ were taken in a dry round bottom flask. 4-methoxybenzene-1,2diamine $(0.01 \mathrm{~mol}, 138.08 \mathrm{gm} / \mathrm{mol}, 1.38 \mathrm{gm})$ was added to it and stirred well to get a clear solution. Carbon disulfide $(0.02 \mathrm{~mol}, 76.14 \mathrm{gm} / \mathrm{mol}, 1.2 \mathrm{ml})$ was added to the clear solution obtained above and refluxed for $12-15 \mathrm{~h}$. The ethanol was distilled off and then cooled to room temperature. The content was poured into water and acidified with diluted 


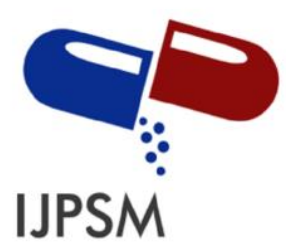

Choudhary Kapil et al, Int. Journal of Pharmaceutical Sciences and Medicine (IJPSM),

Vol.6 Issue. 8, August- 2021, pg. 134-143

ISSN: 2519-9889

Impact Factor: 3.426

$\mathrm{HCl}$ till the precipitates were separated. The separated solid was washed with cold water and dried to get the desired product.

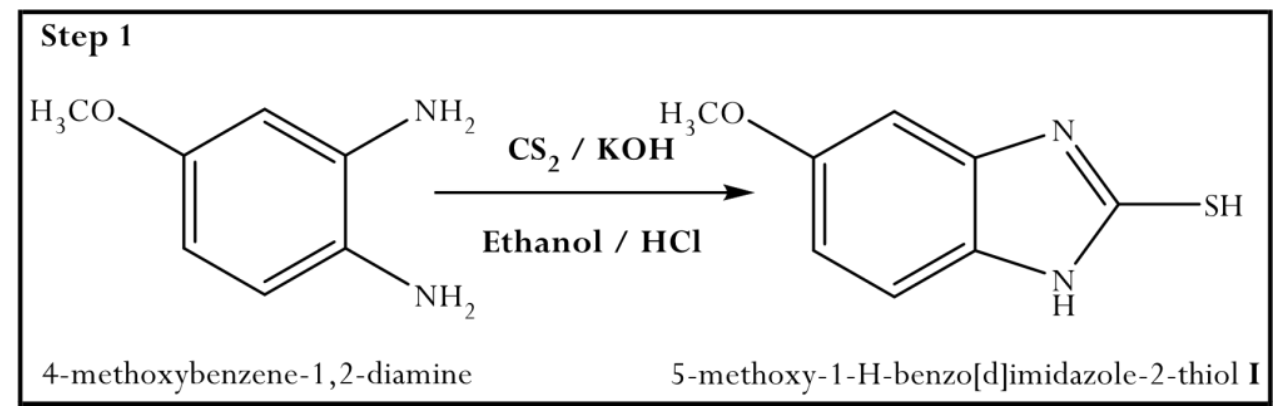

Fig.1 Synthesis of 5-methoxy-1-H-benzo[d]imidazole-2-thiol I

\section{B. Synthesis of 5-(difluoromethoxy)-1H-benzo[d]imidazole-2-thiol I' (step 1)}

Ethanol $(40 \mathrm{ml})$ and potassium hydroxide $\left(0.01 \mathrm{~mol}, 56.11 \mathrm{gm} / \mathrm{mol}, 0.56 \mathrm{gm}\right.$ in $\left.2 \mathrm{ml} \mathrm{H}_{2} \mathrm{O}\right)$ were taken in a dry round bottom flask. 4-(difluoromethoxy) benzene-1,2diamine ( $0.01 \mathrm{~mol}$, $174.14 \mathrm{gm} / \mathrm{mol}, 1.74 \mathrm{gm})$ was added to it and stirred well to get a clear solution. Carbon disulfide $(0.02 \mathrm{~mol}, 76.14 \mathrm{gm} / \mathrm{mol}, 1.2 \mathrm{ml})$ was added to the clear solution obtained above and refluxed for $12-15 \mathrm{~h}$. The ethanol was distilled off and then cooled to room temperature. The content was poured into water and acidified with diluted $\mathrm{HCl}$ till the precipitates were separated. The separated solid was washed with cold water and dried to get the desired product.

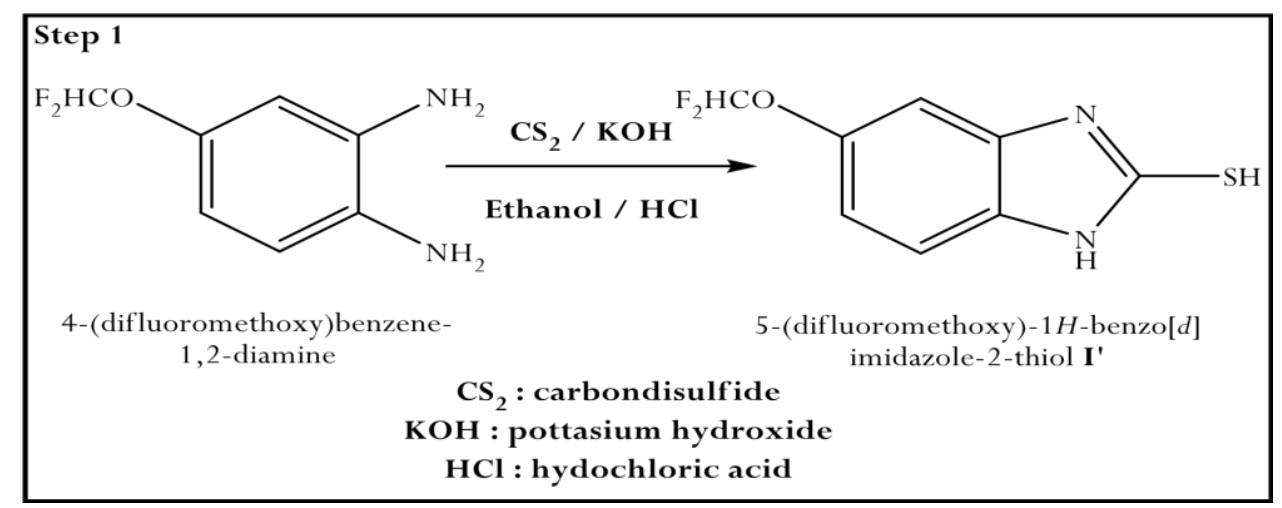

Fig.2 Synthesis of 5-(difluoromethoxy)-1H-benzo[d]imidazole-2-thiol I'

\section{Synthesis of 2-chloro-N-(aryl) acetamide derivatives $I_{1-13}$ and $I_{a-j}$ (step 2)}

Various substituted amines $(0.01 \mathrm{~mol})$ were added to a solution of DMF $(35 \mathrm{ml})$ containing TEA (3-4 drops). The mixture was stirred for 10 minutes at room temperature. CAC (0.015 $\mathrm{mol}, 113 \mathrm{gm} / \mathrm{mol}, 1.19 \mathrm{ml}$ ) was added to the above mixture, maintaining the temperature between 0 to $5^{\circ} \mathrm{C}$. The obtained solution was then stirred at room temperature for $4-6 \mathrm{~h}$. 


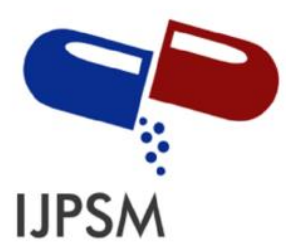

Choudhary Kapil et al, Int. Journal of Pharmaceutical Sciences and Medicine (IJPSM),

Vol.6 Issue. 8, August- 2021, pg. 134-143

ISSN: 2519-9889

Impact Factor: 3.426

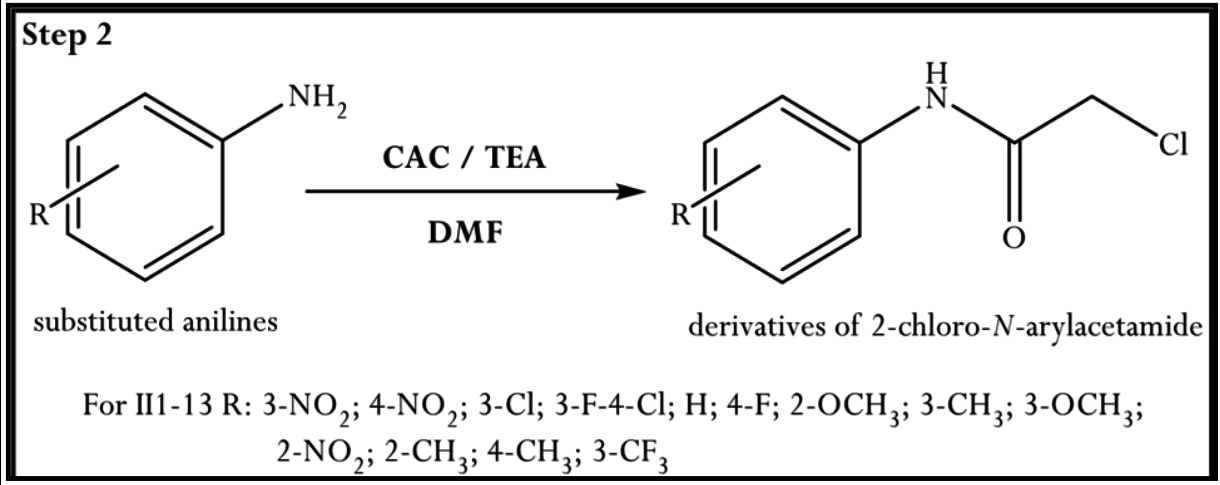

Fig.3 Synthesis of 2-chloro-N-(aryl)acetamide derivatives $\mathrm{II}_{1-13}$

D. Synthesis of 2-(5-methoxy-1H-benzo[d]imidazol-2-ylthio) $\mathrm{N}($ aryl) acetamide derivatives III $_{1-13}$ (step 3)

5-methoxy-1H-benzo[d]imidazole-2-thiol I $(0.01 \mathrm{~mol}, 180 \mathrm{gm} / \mathrm{mol}, 1.8 \mathrm{gm})$ was made soluble in acetone. To this well stirred solution different 2-chloro-Narylacetamide derivatives $\mathbf{I I}_{\mathbf{1 - 1 3}}(0.01 \mathrm{~mol})$ were added to the above solution. $\mathrm{K}_{2} \mathrm{CO}_{3}(0.02 \mathrm{~mol}, 138 \mathrm{gm} / \mathrm{mol}, 2.76 \mathrm{gm})$ was added to the solution containing mixture of 5methoxy-1H-benzo[d]imidazole-2-thiol I and different acetamide derivatives. The mixture was allowed to stir for $4 \mathrm{~h}$ at room temperature.

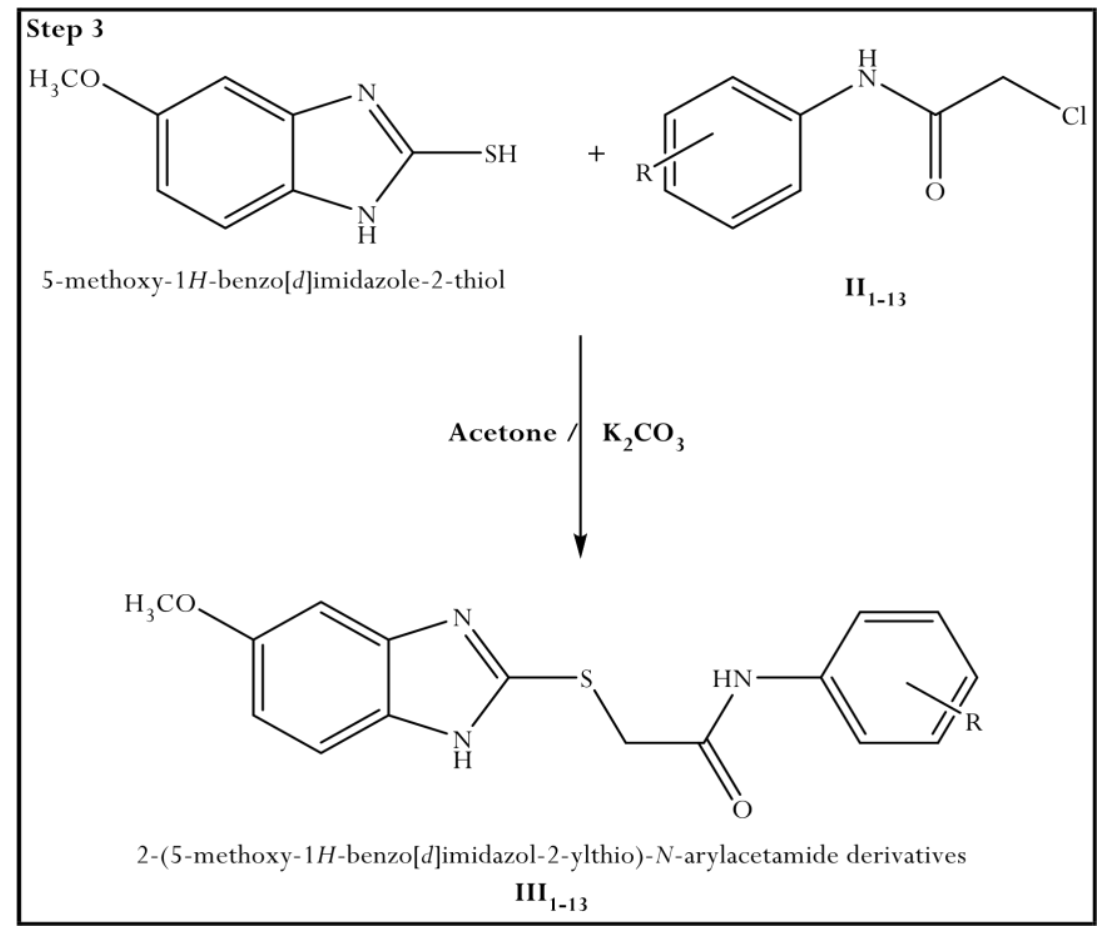

Fig.4 Synthesis of 2-(5-methoxy-1H-benzo[d]imidazol-2-ylthio)N(aryl) acetamide derivatives III $_{1-13}$ 


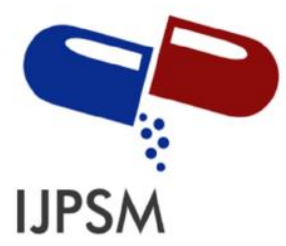

Choudhary Kapil et al, Int. Journal of Pharmaceutical Sciences and Medicine (IJPSM),

Vol.6 Issue. 8, August- 2021, pg. 134-143

ISSN: 2519-9889

Impact Factor: 3.426

\section{SPECTROSCOPIC EXPERIMENTS}

\section{A. Melting point}

Melting point of drug sample was determined by using melting point apparatus. The drug sample was taken and placed in a thin walled capillary tube; the tube was approximately 10$12 \mathrm{~cm}$ in length with $1 \mathrm{~mm}$ in diameter and closed at one end. The capillary was placed in melting point apparatus and heated and when drug sample was melted the melting point of synthesized compound was recorded. The melting point of drug sample was determined by using melting point apparatus. The melting point was found to be in the range of $118-175^{\circ} \mathrm{C}$. The melting point of synthesized compounds are shown in the table:

Table no.1 melting Point of compound III $_{1-13}$

\begin{tabular}{|c|c|c|c|c|c|}
\hline Derivatives & Substituent & Molecular formula & $\begin{array}{c}\text { Molecular } \\
\text { weight } \\
\text { gm/mol }\end{array}$ & m.p. ${ }^{\circ} \mathrm{C}$ & $\begin{array}{c}\text { Yield } \\
\text { Ymol }\end{array}$ \\
\hline $\mathrm{III}_{1}$ & $-3-\mathrm{NO}_{2}$ & $\mathrm{C} 16 \mathrm{H} 14 \mathrm{~N} 4 \mathrm{O} 4 \mathrm{~S}$ & 358 & $118^{\circ} \mathrm{C}$ & $50 \%$ \\
\hline $\mathrm{III}_{2}$ & $-4-\mathrm{NO}_{2}$ & $\mathrm{C} 16 \mathrm{H} 14 \mathrm{~N} 4 \mathrm{O} 4 \mathrm{~S}$ & 358 & $125^{\circ} \mathrm{C}$ & $59 \%$ \\
\hline $\mathrm{III}_{3}$ & $-3-\mathrm{Cl}$ & $\mathrm{C} 16 \mathrm{H} 14 \mathrm{~N} 3 \mathrm{O} 2 \mathrm{SCl}$ & 347 & $121^{\circ} \mathrm{C}$ & $63 \%$ \\
\hline $\mathrm{III}_{4}$ & $-3-\mathrm{F}-4-\mathrm{Cl}$ & $\mathrm{C} 16 \mathrm{H} 13 \mathrm{~N} 3 \mathrm{O} 2 \mathrm{SClF}$ & 365 & $202^{\circ} \mathrm{C}$ & $59 \%$ \\
\hline $\mathrm{III}_{5}$ & $-\mathrm{H}$ & $\mathrm{C} 16 \mathrm{H} 15 \mathrm{~N} 3 \mathrm{O} 2 \mathrm{~S}$ & 313 & $118^{\circ} \mathrm{C}$ & $55 \%$ \\
\hline $\mathrm{III}_{6}$ & $-4-\mathrm{F}$ & $\mathrm{C} 16 \mathrm{H} 14 \mathrm{~N} 3 \mathrm{O} 2 \mathrm{SF}$ & 331 & $158^{\circ} \mathrm{C}$ & $58 \%$ \\
\hline $\mathrm{III}_{7}$ & $-2-\mathrm{OCH}_{3}$ & $\mathrm{C} 17 \mathrm{H} 17 \mathrm{~N} 3 \mathrm{O} 3 \mathrm{~S}$ & 343 & $156^{\circ} \mathrm{C}$ & $44 \%$ \\
\hline $\mathrm{III}_{8}$ & $-3-\mathrm{CH}_{3}$ & $\mathrm{C} 17 \mathrm{H} 17 \mathrm{~N} 3 \mathrm{O} 2 \mathrm{~S}$ & 327 & $105^{\circ} \mathrm{C}$ & $54 \%$ \\
\hline $\mathrm{III}_{9}$ & $-3-\mathrm{OCH}_{3}$ & $\mathrm{C} 17 \mathrm{H} 17 \mathrm{~N} 3 \mathrm{O} 3 \mathrm{~S}$ & 343 & $195^{\circ} \mathrm{C}$ & $62 \%$ \\
\hline $\mathrm{III}_{10}$ & $-2-\mathrm{NO}_{2}$ & $\mathrm{C} 16 \mathrm{H} 14 \mathrm{~N} 4 \mathrm{O} 4 \mathrm{~S}$ & 358 & $105^{\circ} \mathrm{C}$ & $60 \%$ \\
\hline $\mathrm{III}_{11}$ & $-2-\mathrm{CH}_{3}$ & $\mathrm{C} 17 \mathrm{H} 17 \mathrm{~N} 3 \mathrm{O} 2 \mathrm{~S}$ & 327 & $156^{\circ} \mathrm{C}$ & $53 \%$ \\
\hline $\mathrm{III}_{12}$ & $-4-\mathrm{CH}_{3}$ & $\mathrm{C} 17 \mathrm{H} 17 \mathrm{~N} 3 \mathrm{O} 2 \mathrm{~S}$ & 327 & $175^{\circ} \mathrm{C}$ & $76 \%$ \\
\hline $\mathrm{III}_{13}$ & $-3-\mathrm{CF}_{3}$ & $\mathrm{C} 17 \mathrm{H} 14 \mathrm{~N} 3 \mathrm{O} 2 \mathrm{SF}$ & 381 & $109^{\circ} \mathrm{C}$ & $66 \%$ \\
\hline
\end{tabular}




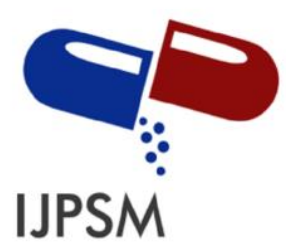

Choudhary Kapil et al, Int. Journal of Pharmaceutical Sciences and Medicine (IJPSM),

Vol.6 Issue. 8, August- 2021, pg. 134-143

ISSN: 2519-9889

Impact Factor: 3.426

\section{B. Determination of Rf value by Thin layer chromatography:}

Rf value of synthesized compounds and the intermediates were determined by Thin Layer Chromatography on glass plates using silica gel-G as absorbent and acetate: benzene $(6: 4 \mathrm{v} / \mathrm{v} \%)$, Toluone : Acetone $(8: 2 \mathrm{v} / \mathrm{v} \%)$ and Ethyl Acetate: $\mathrm{n}$ - Hexane $(6: 4 \mathrm{v} / \mathrm{v} \%)$ as solvent system and spots were detected in iodine chamber. The differences in $\mathrm{Rf}$ value between starting compound and product were indicative of the conversation of starting compound into the product. Rf values are mentioned in table no. 8.2.1.

Table no. 2: Molecular Formula, Rf value, solvent system of compound III 1-13

\begin{tabular}{|c|c|c|c|}
\hline Derivative & Molecular formula & Rf & Solvent system \\
\hline $\mathrm{III}_{1}$ & C16H14N4O4S & 0.71 & Ethyl acetate: Benzene (6:4) \\
\hline $\mathrm{III}_{2}$ & C16H14N4O4S & 0.69 & Ethyl acetate: Benzene (6:4) \\
\hline $\mathrm{III}_{3}$ & $\mathrm{C} 16 \mathrm{H} 14 \mathrm{~N} 3 \mathrm{O} 2 \mathrm{SCl}$ & 0.72 & Ethyl acetate: Benzene (6:4) \\
\hline $\mathrm{III}_{4}$ & $\mathrm{C} 16 \mathrm{H} 13 \mathrm{~N} 3 \mathrm{O} 2 \mathrm{SClF}$ & 0.65 & Ethyl acetate: Benzene (6:4) \\
\hline $\mathrm{III}_{5}$ & C16H15N3O2S & .067 & Ethyl acetate: Benzene (6:4) \\
\hline $\mathrm{III}_{6}$ & C16H14N3O2SF & 0.63 & Ethyl acetate: Benzene (6:4) \\
\hline $\mathrm{III}_{7}$ & C17H17N3O3S & 0.62 & Ethyl acetate: Benzene (6:4) \\
\hline $\mathrm{III}_{8}$ & C17H17N3O2S & 0.73 & Ethyl acetate: Benzene (6:4) \\
\hline $\mathrm{III}_{9}$ & C17H17N3O3S & 0.64 & Ethyl acetate: Benzene (6:4) \\
\hline $\mathrm{III}_{10}$ & C16H14N4O4S & 0.74 & Ethyl acetate: Benzene (6:4) \\
\hline $\mathrm{III}_{11}$ & C17H17N3O2S & 0.65 & Ethyl acetate: Benzene (6:4) \\
\hline $\mathrm{III}_{12}$ & C17H17N3O2S & 0.67 & Ethyl acetate: Benzene (6:4) \\
\hline $\mathrm{III}_{13}$ & C17H14N3O2SF & 0.75 & Ethyl acetate: Benzene (6:4) \\
\hline
\end{tabular}

\section{Infra-red spectral Analysis}

\section{Spectral interpretation for compound III $_{13}$}

If we observe the data for 2-(5-methoxy-1H-benzo[d]imidazol-2-ylthio)-N (3(trifluoromethyl) phenyl) acetamide III $_{13}$, An absorption peak obtained at $3393 \mathrm{~cm}^{-1}$ has helped in confirming the presence of $-\mathrm{NH}$ in vicinity to the carbonyl group. The presence of aromatic $\mathrm{C}-\mathrm{H}$ linkage is confirmed by the peak obtained at $3095 \mathrm{~cm}^{-1}$. A sharp peak at $2921 \mathrm{~cm}^{-1}$ helped to assign the presence of $-\mathrm{C}-\mathrm{H}$ bond in $-\mathrm{OCH}_{3}$ group. A stretching band at $2853 \mathrm{~cm}^{-1}$ concluded the presence of methylene group in the final motif. The presence of carbonyl $(-\mathrm{C}=\mathrm{O})$ in the structure is proved due to the presence of a sharp peak at $1698 \mathrm{~cm}^{-1}$. The presence of $-\mathrm{C}=\mathrm{N}$ in the Benz imidazole nucleus was also confirmed by the presence of a sharp absorption band at $1580 \mathrm{~cm}^{-1}$. 


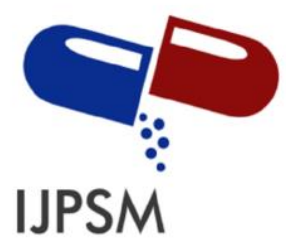

Choudhary Kapil et al, Int. Journal of Pharmaceutical Sciences and Medicine (IJPSM),

Vol.6 Issue. 8, August- 2021, pg. 134-143

ISSN: 2519-9889

Impact Factor: 3.426

Table no 3: IR spectral data for compound $\mathrm{III}_{13}$

\begin{tabular}{|l|l|l|l|}
\hline Functional group & $\begin{array}{l}\text { Frequency } \\
\left(\mathbf{C m}^{-\mathbf{1}}\right)\end{array}$ & Functional group & $\begin{array}{l}\text { Frequency } \\
\left(\mathbf{C m}^{-\mathbf{1}}\right)\end{array}$ \\
\hline -N-H sec. amine (str.) & 3393 & $\begin{array}{l}\text {-C=O carbonyl group } \\
\text { (str.) }\end{array}$ & 1698 \\
\hline -C-H aromatic ring (str.) & 3095 & $-\mathrm{C}=\mathrm{N}$ sec. amine (str.) & 1580 \\
\hline -C-H methoxy group (str.) & 2921 & -C-F (str.) & 1161 \\
\hline$-\mathrm{CH}_{2}$ methylene group (str.) & 2853 & -Nil- & -Nil- \\
\hline
\end{tabular}
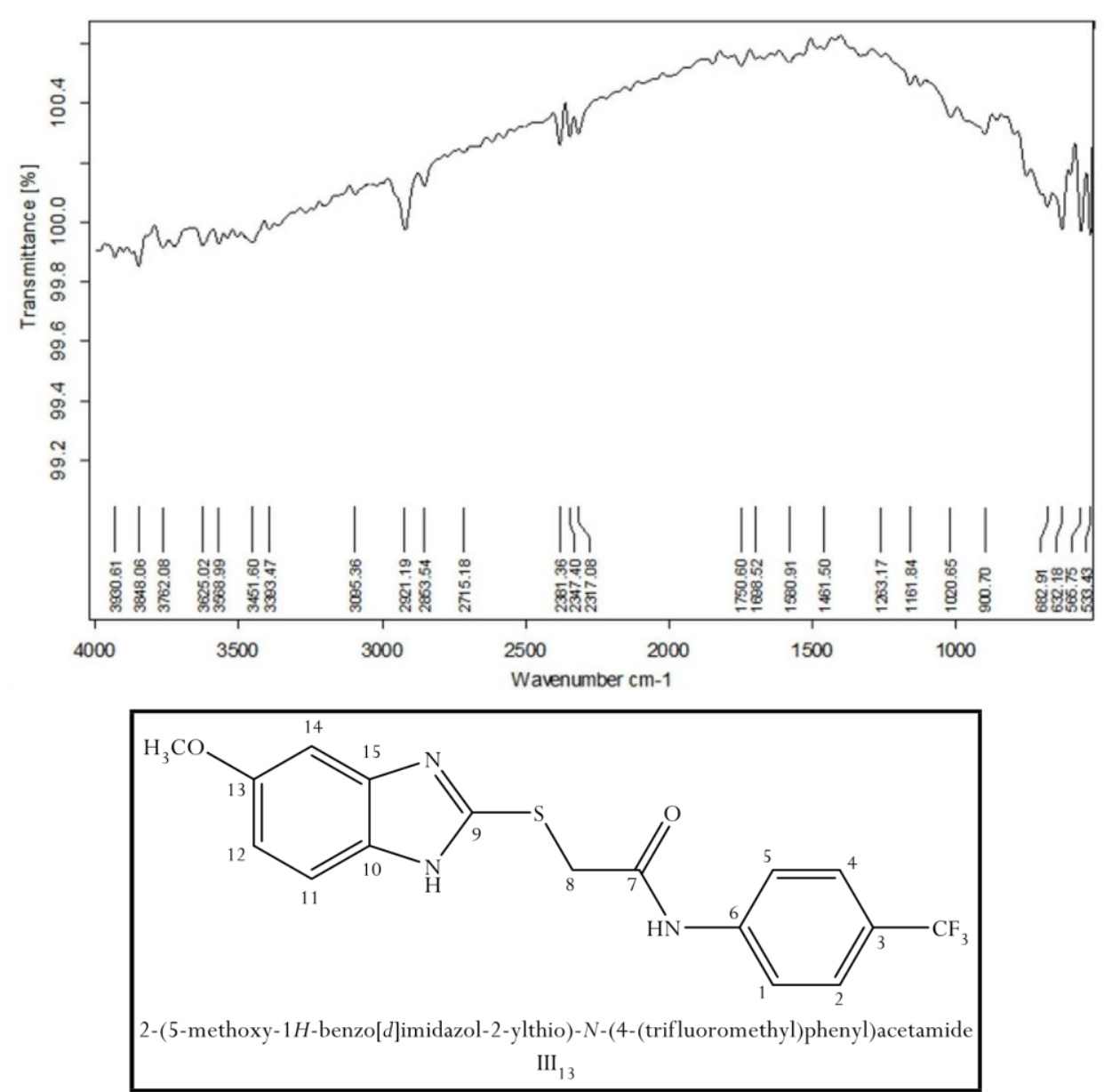

Fig. 2 IR spectra for compound $\mathrm{III}_{13}$ 


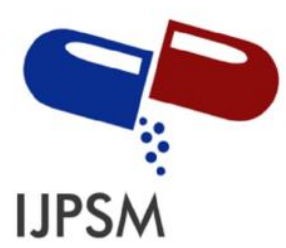

Choudhary Kapil et al, Int. Journal of Pharmaceutical Sciences and Medicine (IJPSM),

Vol.6 Issue. 8, August- 2021, pg. 134-143

ISSN: 2519-9889

Impact Factor: 3.426

\section{BIOLOGICAL EVALUATION OF SYNTHESIZED COMPOUND}

Therapeutic studies - antimicrobial studies

The results obtained were depicted in the form of Minimum Inhibitory Concentration (MIC) values for the synthesized derivatives. The samples were tested by standard protocols like micro dilution/broth titer method. The antibacterial and antifungal details for each compound synthesized are discussed below.

\section{Antibacterial Properties for compounds III $_{1-13}$}

Gram-positive bacteria S. aureus (ATCC No. 25923) and E. faecalis (ATCC No. 27853) were introduced for testing the antibacterial potential of the synthesized molecules $\mathbf{I I I}_{\mathbf{1 - 1 3}}$. When tested against $S$. aureus, it was found that from the complete series synthesized, compounds $\mathbf{I I I}_{\mathbf{9}}\left(\mathrm{p}-\mathrm{OCH}_{3}\right)$ and $\mathbf{I I I}_{10}\left(\mathrm{o}-\mathrm{NO}_{2}\right)$ exhibited activity equivalent to that of the standard ciprofloxacin $(62.5 \mu \mathrm{g} / \mathrm{ml})$. Other derivatives from the series exhibited higher MIC value than the standard resulting in poor results against gram-positive bacteria $S$. aureus. Similarly the synthesized series was tested against another gram-positive bacterial strain E. faecalis, where it was observed that the derivatives $\mathbf{I I I}_{\mathbf{3}}(\mathrm{m}-$ $\mathrm{Cl}), \mathbf{I I I}_{\mathbf{4}}(3-\mathrm{F}-4-\mathrm{Cl}), \mathbf{I I I}_{5}(\mathrm{H}), \mathbf{I I I}_{\mathbf{9}}\left(\mathrm{p}-\mathrm{OCH}_{3}\right), \mathbf{I I I}_{\mathbf{1 0}}\left(\mathrm{o}-\mathrm{NO}_{2}\right)$ and $\mathbf{I I I}_{\mathbf{1 1}}\left(\mathrm{o}-\mathrm{CH}_{3}\right)$ exhibited equivalent (125 $\mu \mathrm{g} / \mathrm{ml}$ ) activity as compared to the standard. Overall half of the derivatives showed equivalent activity against gram-positive bacteria $S$. aureus and E. faecalis when compared with the standard drug ciprofloxacin. The final derivatives III $_{\mathbf{1 - 1 3}}$ were also tested against two gram-negative bacteria $E$. coli (ATCC No. 25922) and P. aeruginosa (27853) and compared with the same standard ciprofloxacin. The results of most of the compounds as antibacterial were excellent against both the gram-negative bacterial strains. The compounds III $_{4}(3-\mathrm{F}-4-\mathrm{Cl}), \mathbf{I I I}_{\mathbf{5}}(\mathrm{H}), \mathbf{I I I}_{6}(\mathrm{p}-\mathrm{F}), \mathbf{I I I}_{\mathbf{1 0}}\left(\mathrm{o}-\mathrm{NO}_{2}\right), \mathbf{I I I}_{\mathbf{1 1}}\left(\mathrm{o}-\mathrm{CH}_{3}\right), \mathbf{I I I}_{\mathbf{1 2}}$ $\left(\mathrm{p}-\mathrm{CH}_{3}\right)$ and $\mathrm{III}_{13}\left(\mathrm{~m}-\mathrm{CF}_{3}\right)$ showed MIC value $(62.5 \mu \mathrm{g} / \mathrm{ml})$ even better than that of the standard drug ciprofloxacin proving excellent potency as antibacterial. The remaining derivatives from the same series which included $\mathbf{I I I}_{\mathbf{1}}\left(\mathrm{m}-\mathrm{NO}_{2}\right), \mathbf{I I I}_{\mathbf{2}}\left(\mathrm{p}-\mathrm{NO}_{2}\right), \mathbf{I I I}_{\mathbf{3}}(\mathrm{m}-\mathrm{Cl}), \mathbf{I I I}_{\mathbf{8}}\left(\mathrm{m}-\mathrm{CH}_{3}\right), \mathbf{I I I} \mathbf{9}\left(\mathrm{p}-\mathrm{OCH}_{3}\right)$ exhibited activity equivalent to the standard $(125 \mu \mathrm{g} / \mathrm{ml})$. These derivatives when tested against $P$. aeruginosa also resulted in very good antibacterial activity. Compounds $\mathbf{I I I}_{\mathbf{1}}\left(\mathrm{m}-\mathrm{NO}_{2}\right), \mathbf{I I I}_{\mathbf{2}}\left(\mathrm{p}-\mathrm{NO}_{2}\right), \mathbf{I I I}_{\mathbf{3}}(\mathrm{m}-\mathrm{Cl})$, III $_{4}$ (3-F-4-Cl) and III $_{9}\left(\mathrm{p}-\mathrm{OCH}_{3}\right)$ showed excellent activity $(62.5 \mu \mathrm{g} / \mathrm{ml})$, even better than ciprofloxacin. There were other compounds exhibiting equivalent activity $(125 \mu \mathrm{g} / \mathrm{ml})$ as compared to the standard viz. $\mathbf{I I I}_{\mathbf{5}}(\mathrm{H}), \mathbf{I I I}_{\mathbf{6}}(\mathrm{p}-\mathrm{F}), \mathbf{I I I}_{\mathbf{1 0}}\left(\mathrm{o}-\mathrm{NO}_{2}\right), \mathbf{I I I}_{\mathbf{1 1}}\left(\mathrm{o}-\mathrm{CH}_{3}\right), \mathbf{I I I}_{\mathbf{1 2}}\left(\mathrm{p}-\mathrm{CH}_{3}\right)$ and $\mathbf{I I I}_{\mathbf{1 3}}\left(\mathrm{m}-\mathrm{CF}_{3}\right)$. Thus from the series of synthesized derivatives $\mathbf{I I I}_{\mathbf{1 - 1 3}}$ more than half of the compounds showed equivalent activity. 


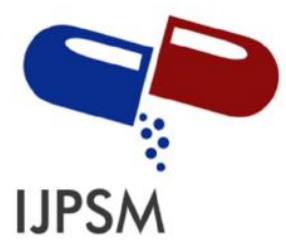

Choudhary Kapil et al, Int. Journal of Pharmaceutical Sciences and Medicine (IJPSM),

Vol.6 Issue. 8, August- 2021, pg. 134-143

ISSN: 2519-9889

Impact Factor: 3.426

Table 4: Antimicrobial screening for compounds III $_{1-13}$

\begin{tabular}{|c|c|c|c|c|c|c|}
\hline \multirow{3}{*}{ Compounds } & \multicolumn{6}{|c|}{ Minimum Inhibitory Concentration (MIC) in $\mu \mathrm{g} / \mathrm{ml}$} \\
\cline { 2 - 7 } & Gram-positive bacteria & \multicolumn{2}{c|}{ Gram-negative bacteria } & \multicolumn{1}{c|}{ Fun } & Gi \\
\cline { 2 - 7 } & $\begin{array}{c}\text { S. aureus } \\
\text { ATCC 25923 }\end{array}$ & $\begin{array}{c}\text { E. faecalis } \\
\text { ATCC 29212 }\end{array}$ & $\begin{array}{c}\text { E. coli } \\
\text { ATCC 25922 }\end{array}$ & $\begin{array}{c}\text { P. aeruginosa } \\
\text { ATCC 27853 }\end{array}$ & $\begin{array}{c}\text { C. albicans } \\
\text { ATCC 10231 }\end{array}$ & $\begin{array}{c}\text { A. niger } \\
\text { ATCC 1015 }\end{array}$ \\
\hline III $_{1}$ & 250 & 250 & 125 & 62.5 & 250 & 250 \\
\hline $\mathrm{III}_{2}$ & 125 & 250 & 125 & 62.5 & 125 & 250 \\
\hline $\mathrm{III}_{3}$ & 125 & 125 & 125 & 62.5 & 125 & 250 \\
\hline $\mathrm{III}_{4}$ & 125 & 125 & 62.5 & 62.5 & 125 & 250 \\
\hline $\mathrm{III}_{5}$ & 125 & 125 & 62.5 & 125 & 125 & 125 \\
\hline $\mathrm{III}_{6}$ & 125 & 250 & 62.5 & 125 & 125 & 125 \\
\hline $\mathrm{III}_{7}$ & 31.25 & 125 & 62.5 & 125 & 250 & 125 \\
\hline $\mathrm{III}_{8}$ & 250 & 250 & 125 & 250 & 250 & 250 \\
\hline $\mathrm{III}_{9}$ & 62.5 & 125 & 125 & 62.5 & 250 & 250 \\
\hline $\mathrm{III}_{10}$ & 62.5 & 125 & 62.5 & 125 & 250 & 250 \\
\hline $\mathrm{III}_{11}$ & 125 & 125 & 62.5 & 125 & 125 & 125 \\
\hline $\mathrm{III}_{12}$ & 250 & 250 & 62.5 & 125 & 250 & 250 \\
\hline $\mathrm{III}_{13}$ & 250 & 250 & 62.5 & 125 & 250 & 125 \\
\hline Ciprofloxacin & 62.5 & 125 & 125 & 125 & - & - \\
\hline
\end{tabular}

\section{CONCLUSION}

From the antimicrobial results carried above, it can be concluded that the derivatives possessing electron with-drawing substituent were found to exhibit excellent antimicrobial property in $\mathbf{I I I}_{\mathbf{1 - 1 3}}$. On the basis of above results, attempts are made to optimize the lead structure to obtain more potent antimicrobial molecules. The series of synthesized derivatives $\mathbf{I I I}_{\mathbf{1 - 1 3}}$ more than half of the compounds showed equivalent activity. Antimicrobial screening of the compounds $\mathrm{III}_{1-13}$ up to a great extent have proved to be potent antibacterial agents. In this study we have synthesized a novel series of 1, 2benzimidazole derivatives starting from easily available starting materials. Using this method we have prepared series of 1,2-disubstituted benzimidazoles containing pyrimidine and other functional groups, which provides advantages such as, easy workup and high yield.

\section{ACKNOWLEDGEMENT}

The author is thankful to the management of Swami Vivekanand College of pharmacy Indore. For providing necessary facilities to carry out the research work and heartily thankful to my guide and co- 


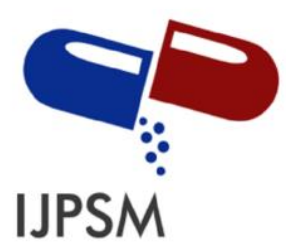

Choudhary Kapil et al, Int. Journal of Pharmaceutical Sciences and Medicine (IJPSM), Vol.6 Issue. 8, August- 2021, pg. 134-143

ISSN: 2519-9889

Impact Factor: 3.426

guide Ms. Rupali Bhavsar and Mrs. Prerna Chaturvedi for providing all the support and encouragement to carry out this studies.

\section{REFERENCES}

[1]. Foster, J. E.; Nicholson, J. M.; Butcher, R.; Stables, J. P.; Edafiogho, I. O.; Goodwin, A. M.; Henson, M. C.; Smith, C. A.; Scott, K. R. Bioorg. Med. Chem. 1999, 7, 2415.

[2]. Boger, D. L.; Ishizaki, T.; Wysocki, J. R. J.; Munk, S. A.; Kitos, P. A.; Suntornwar, O. J. Am. Chem. Soc. 1989, 111, 6461. (b) Wang, Y. F.; Izawa, T.; Kobayashi, S.; Ohno, M. J. Am. Chem. Soc. 1982, $104,6465$.

[3]. Devender, P.; Nadeem, S.; Bhanupriya, B.; Ahsanb, W.; Shamsher Alam, M. Der Pharmacia Lettre., 2010, 2(2), 27.

[4]. Alexander, B. D. and Perfect, J. R., Antifungal resistance trends towards the year 2000 Implications for therapy and new approaches.Drugs, 54, 657-678 (1997)PubMedGoogle Scholar

[5]. Amyes, S. G. B. and Gemmell, C. G., Antibiotic resistance-Proceedings of a symposium held on 12 July 1996 at the University of Southampton.J. Med. Microbiol., 46, 436-470 (1997)CrossRefGoogle Scholar

[6]. Ates, Ö., Altintas, H. and Ötük, G., Synthesis and antimicrobial activity of 4-carbethoxymethyl-2[(alpha-haloacyl)amino] thiazoles and 5-nonsubstituted/substituted 2-[(4-carbethoxymethylthiazol2-yl) imino]-4-thiazolidinones.Arzneim. Forsch., 50, 569-575 (2000).Google Scholar

[7]. Cassell, G. H. and Mekalanos, J., Development of antimicrobial agents in the era of new and reemerging infectious diseases and increasing antibiotic resistance.J. Am. Med. Assoc., 285, 601605 (2001).CrossRef Google Scholar

[8]. Cetinkaya, Y., Falk, P., and Mayhall, C.G., Vancomycin-resistant enterococci.Clin. Microbiol. Rev., 13, 686-707 (2000).PubMedCrossRef Google Scholar

[9]. Chu, D. T. W., Plattner, J. J., and Katz, L., New directions in antibacterial research.J. Med. Chem., 39, 3853-3874 (1996).PubMed CrossRef Google Scholar

[10].Cunha, B. A., Antibiotic resistance.Drugs Today, 34, 691-698 (1998).PubMedGoogle Scholar

[11].Doern, G. V., Antimicrobial use and the emergence of antimicrobial resistance with Streptococcus pneumoniae in the United States.Clin. Infect. Dis., 33, 187-192 (2001).CrossRefGoogle Scholar 